\title{
BETWEEN EAST AND WEST. ORTHODOX TEMPLA AND LATIN TRAMEZZI AT THE LATE MEDIEVAL CRETAN CHURCHES*
}

\section{ATHANASSIOS MAILIS}

UDC: $72.033 \cdot 2: 726.54(495.9) " 13 / 14 "$

Review

Manuscript received: 10. 11. 2015.

Revised manuscript accepted: 28. 03. 2016.

DOI: 10.1484/J.HAM.5.111364

\author{
A. Mailis \\ Curator of Byzantine Antiquities \\ Hellenic Ministry of Culture-Ephorate of Antiquities Chania \\ Sourmeli 24, Chania 731 oo \\ Greece
}

This study researches an individual group of templon screens, which are found at three Cretan churches of the $14^{\text {th }} / 15^{\text {th }} c$. This group displays typological and morphological features, which seem to break with the tradition of the middle Byzantine templa and to suggest the influence of a Latin architectural model. The specific Cretan group has much in common with façades of choir partitions (tramezzi), mostly of Italian origin. Despite the absence of sufficient archaeological evidence concerning the existence of tramezzi at the Helladic area, the written sources suggest the presence of such installations at the Latin churches of Crete, thus reinforcing the possibility of cultural and cultic exchanges between the Latin and the Orthodox populations of the island during the Late Medieval period.

Keywords: Medieval Period, Crete, Architectural Sculpture, Screens.

The Medieval edifices of Crete often puzzle their researchers, who are usually trained as historians of Byzantine architecture. This bewilderment relies on the contradiction between the architectural forms known to them by the Handbooks of Byzantine art and the reality displayed by the Cretan monuments themselves. It seems that sometimes, on Crete, the standard architectural types are modified

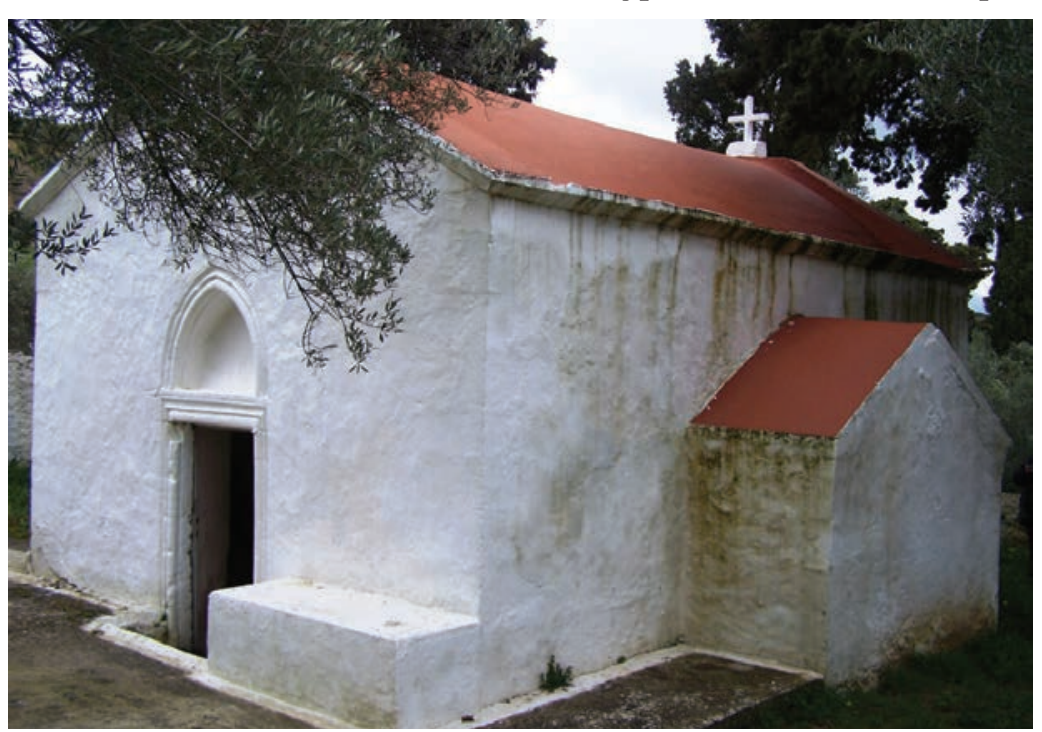

Fig. 1 The church of the Transformation of the Savior, Vutufou (author). to such an extended degree, so as the new forms can be hardly characterized as "Byzantine", yet still point at their "Byzantinism" as a source. Through this prism it would be plausible to describe this characteristic as the byzantinishe Ungehörigkeit of the Cretan Medieval churches.

One factor of major importance for the creation of this phenomenon is the influence of the Western models and the adoption mechanism on behalf of the local architecture. This process does not include only architectural forms ${ }^{1}$ but also liturgical installations such as the templon screens. This study researches a specific group of screens at the churches of: a) The Transformation of the Savior at Leucochori (Vutufou) at the Pediada district of Heraklion, b) St. John the Theologian at the settlement of Margarites, Rethymnon, c) Hagios Nikolaos Chostos near the settlement of Argyroupolis, Rethymnon. These three furnishings serve the liturgical needs of the Orthodox Liturgy, yet demonstrate morphological characteristics that affiliate with the remark mentioned above.

The church consecrated to the Transformation of the Savior is located at the rural site "Monastira" outside the settlement of Leucochori, approximately 40 klms SE. from Heraklion ${ }^{2}$ (Fig.1). This single aisled church $\left(5,78 \mathrm{X}_{3}, 42 \mathrm{~m}\right.$.) is equipped with two projected lateral wings that were probably used as arcosolia.

\footnotetext{
* For the completion of this study I would like to thank the Ephoreia Archaeoteton Rethymnou for granting me the permission to research the screens of Margarites and Argyroupoli; P. Epitropakis for allowing me to study the templon of Vutufou; G. Perivola who draw and corrected the plans of all three screens. For the useful discussions I owe many thanks to S. Mamaloukos, M. Vakondiou, the Franciscan monk N. Roussos and especially P. Modesti and M. Mersch, who shared their knowledge on the Venetian tramezzi and German Lettner.

A first version of this paper was presented at the 35 th Symposium of Byzantine and Post-Byzantine archaeology and art, as: Mailis Th., Templa and Tramezzi at the Cretan Churches of the Late Medieval Period in: 35th Symposium of Byzantine and Post-Byzantine archaeology and art, Athens, 2015, 62-3 (Greek).

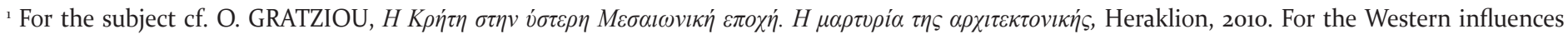

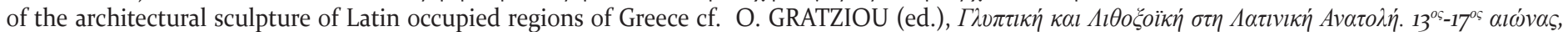
Heraklion 2007.

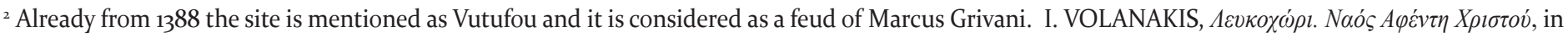
Archaeologikon Deltion 62, 2007, B2, p. 1271.
} 


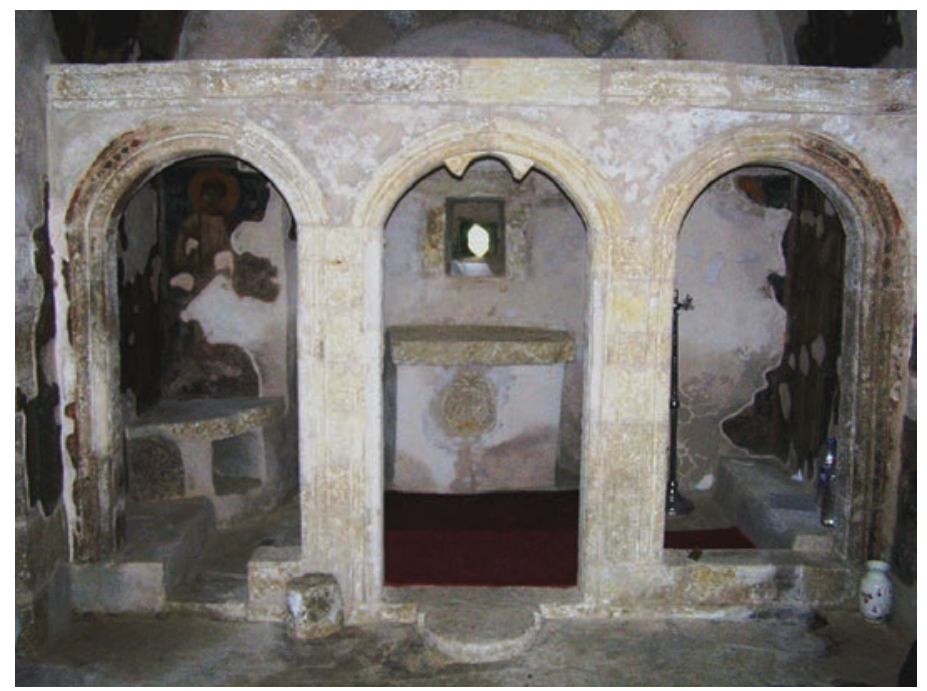

Fig. 2 The templon at the church of the Transformation, Vutufou (author).

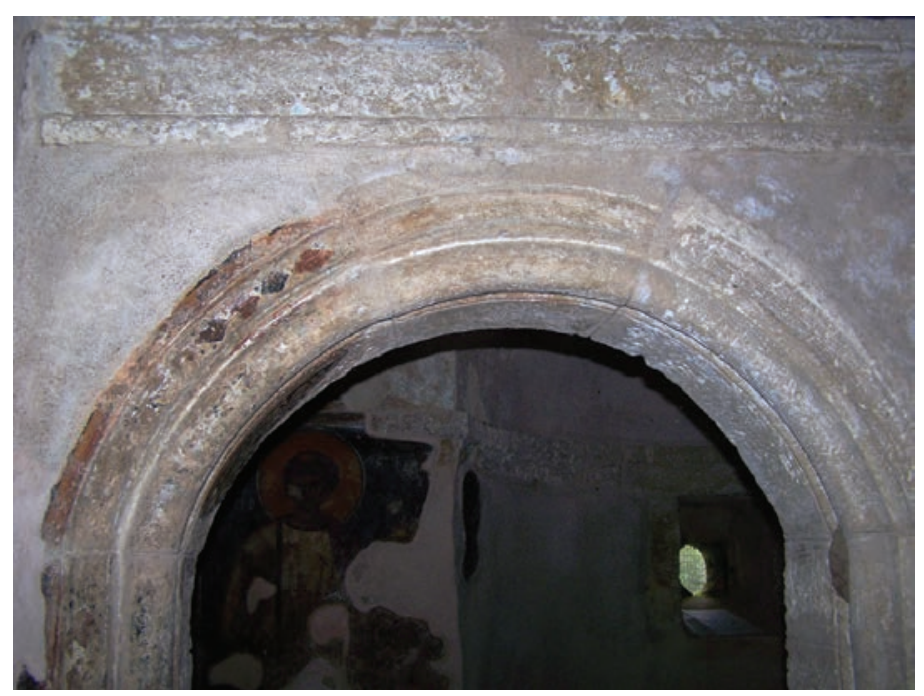

Fig. 4 Extrado of the N. arch of the templon, Vutufou (author).

The researcher of the church classified it under a group of individual cross-roof churches and he dated it ca.1320-1330, on the basis of the fresco decoration of its western part ${ }^{3}$. A second group of murals situated at the eastern part can be dated at the second half of the $14^{\text {th }}$ c.-early $15^{\text {th }} \mathrm{c}$. due to its forward style in comparison with the previous group. In the early $2 \mathrm{O}^{\text {th }} \mathrm{c}$. G. Gerola had recorded the screen of the church (Fig. 2, 3) ${ }^{4}$. The installation is contemporary with the frescoes of the eastern part as it is implied by the red painted lines, which define the limits of the mural decoration. The

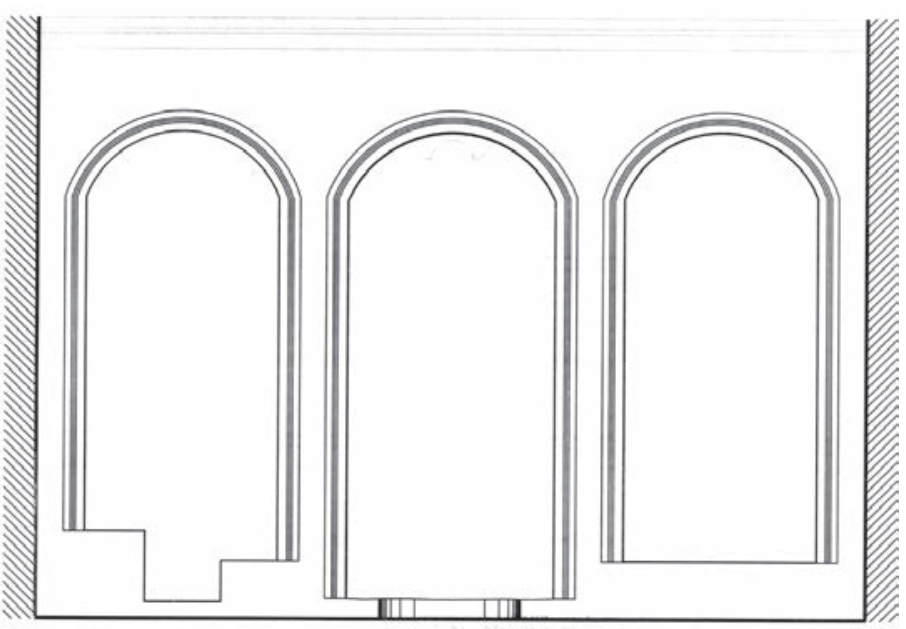

\section{$\overbrace{}^{1}=\underbrace{2} \underbrace{3}$}

Fig. 3 The templon at the church of the Transformation, Vutufou (design G. Kontogiannis/G. Perivola).

screen $(3,50 \mathrm{~m}$. width, $2,50 \mathrm{~m}$. height) is built on a podium. It consists of an open triple arcade complemented with a stone cornice. The semicircular/segmental arches share similar dimensions (o, 80-0, $83 \mathrm{~m}$. width) and identical frames adorned with a rib, a deep carved band and a broad flat raised strip, a usual decoration for the portals of the $15^{\text {th }}$ c. Cretan Churches 5 . A quite unusual architectural feature is the small arched frame that springs from the middle of the soffit of the central arch. Additionally a painted series of double-colored rhombuses decorates the northern arch extrado, while its soffit preserves aniconic decoration patterns $^{6}$ (Fig. 4). At the lower part of the northern wall of the same arch there is constructed a bench $(0,38 \mathrm{~m}$. height), while a step $(0,12 \mathrm{~m}$.) is attached at the northern pier of the screen. The lower part of the southern arch preserves a stepped frame (o, 12m.).

The screen was constructed with carved small blocks and minimal intermediary joints. Both plan and execution imply an elaborate design. The decorative sculpture of the central arch gives the faulty impression of an unfinished trefoil arch, similar to those of the Gothic and some contemporary Cretan churches. In fact, it is an isolated arched frame resembling decorative arches of 13 th c. Western churches ${ }^{7}$, as well as frames of posterior wooden iconostasis ${ }^{8}$. The painted double-colored rhombuses of the northern arch extrado recall decorative practices of Gothic portals 9 . The pattern is common for the decoration of façades at $13^{\text {th }} \mathrm{c}$. Italian

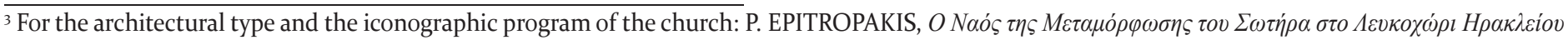

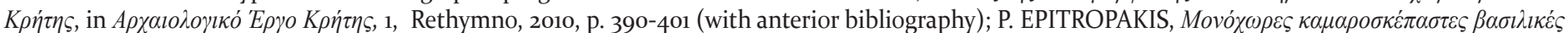

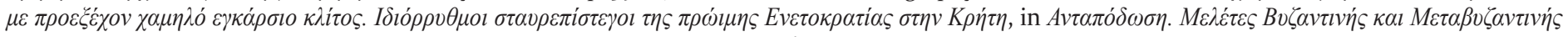

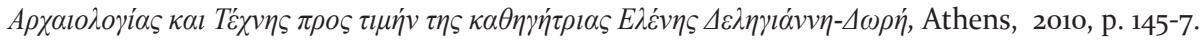

${ }_{4}$ Ci piace ricordare la serraglia in muro con tre archi, gia lavovati in stile gotico a S. Giorgio presso Vutufü. The church is known to Gerola as Hagios Georgios.. G. GEROLA, Monumenti Veneti nell' Isola di Creta. Ricerche e descrizione fatte dal Dottor G. Gerola per incarico der R. Instituto, II, Venice, 1908, p. 348 no. 2 .

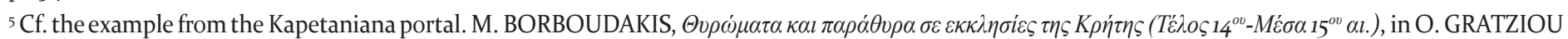

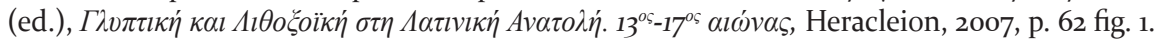

${ }^{6}$ P. EPITROPAKIS, op. cit (n. 3), p. 390.

7 J. JUNG, The unifying role of the Choir Screen in Gothic Churches, in Art Bulletin 82, 2000, p. 638-9, fig. 16-7.

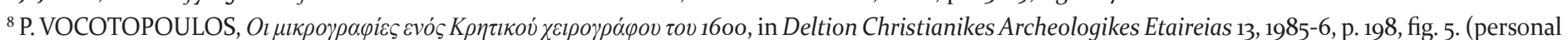
observation of Maria Vakondiou who kindly informed me about the reference).

9 For examples from Gothic churches of the Greek mainland cf. the fresco-painted extrados from the portals of the church at Clarence (Glarentza). D. ATHANASOULIS, $\Gamma \lambda \alpha \rho \varepsilon ́ v \tau \zeta \alpha$-Clarence, Athens, 2005, p. 39-40. 


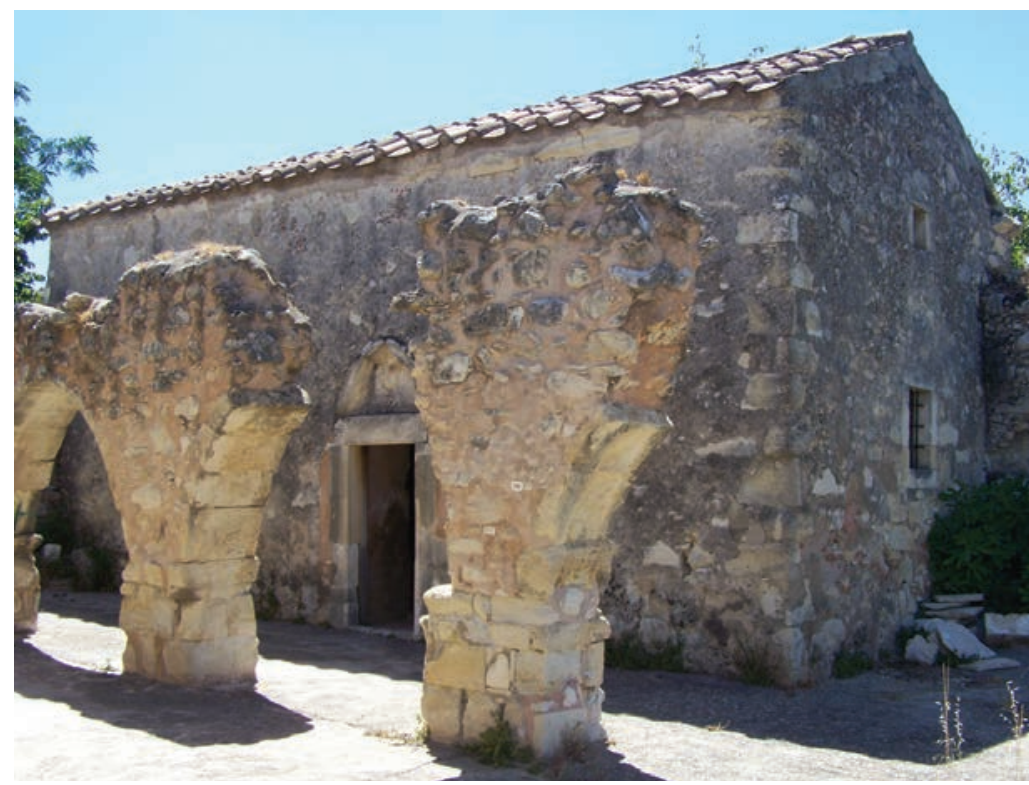

Fig. 5 St. John the Theologian, Margarites Rethymno (author).

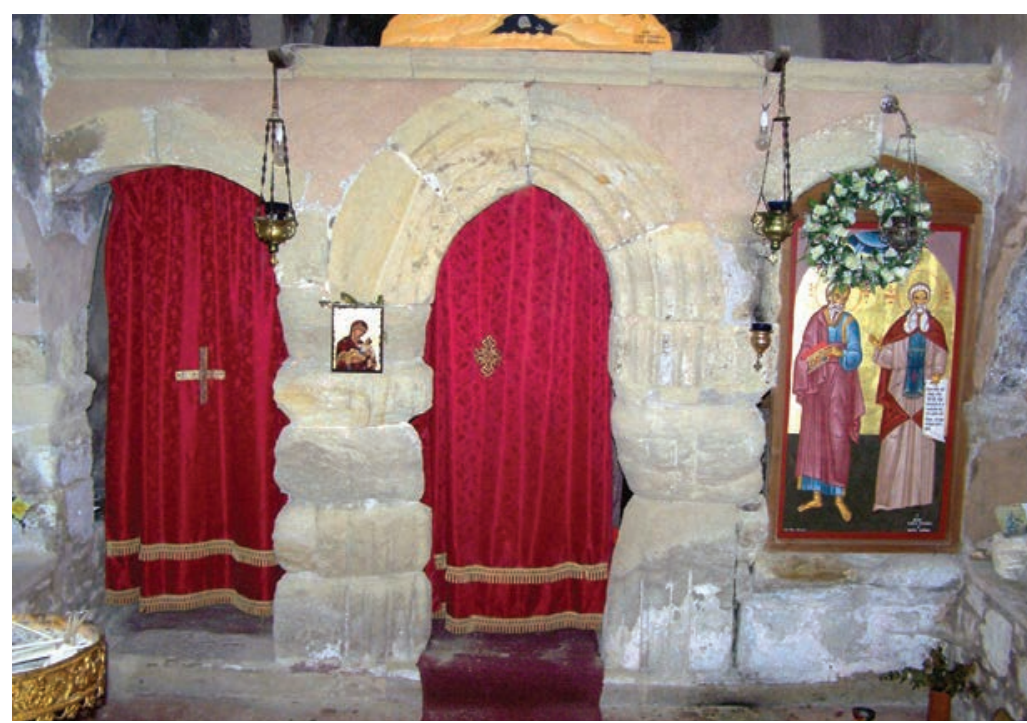

Fig. 6 The templon at the church of St. John the Theologian, Margarites (author).

churches-as they are depicted at Giotto's frescoes ${ }^{10}$ and it is also found at the extrado of the entrance at the church of Holy Cross in Valsamonero, Crete ${ }^{11}$.

The function of the openings remains dubious. According to P. Epitropakis they were used for the adjustment of large portable icons suitable for prostration ${ }^{12}$. This interpretation could be plausible for the southern arch, which preserves a stepped frame along its lower side that could be used as a pedestal. Yet, it is highly speculative for the northern arch

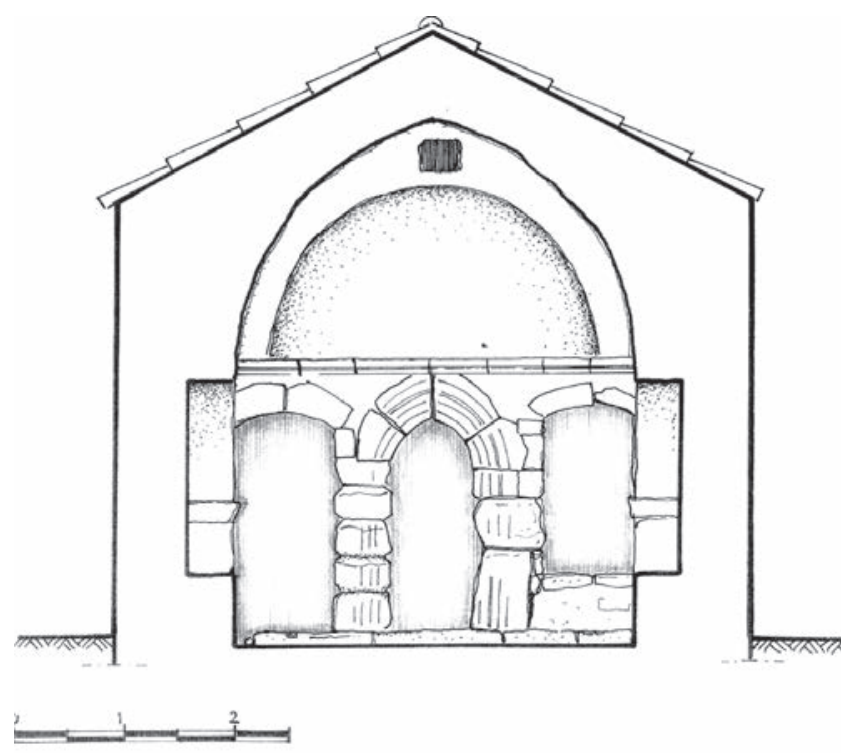

Fig. 7 The templon at Margarites, present phase (design: G. Perivola).

due to the inequality of heights between the bench of the wall and the step of the N. pier. The northern arch was probably used as a passageway for the processions of the Little and Great Entrances. It is noteworthy that the triple arcade of the specific screen gives the delusive impression of a tripartite Holy Bema, although the sanctuary remains a sole room as in the majority of the single-aisled churches of the island. Eventually both elaborate construction and suggested monumentality imply that the Vutufou Screen possibly imitated a more sophisticated prototype on a modest scale.

One can make similar observations for the screen of St. John the Theologian. The church (Fig. 5) is located in Margarites (ca. $27 \mathrm{klms}$ SE. from Rethymnon), a flourishing settlement of the Venetian period as implied by the surviving monuments ${ }^{13}$. The single-aisled church of St. John ${ }^{14}(10,03$ X 5,71 m.) was decorated with four pairs of lateral blind arches and it was equipped with a semicircular bench attached to the apsis, thus resembling a "synthronon". The vaults of the church are elevated $(4,60 \mathrm{~m}$.) in comparison with the average height of the Cretan churches (ca. $3 \mathrm{~m}$.). The screen, which is built simultaneously with the church, adjusts its large dimensions $(3,60 \mathrm{~m}$. width, $2,45 \mathrm{~m}$. height $)$ with the high analogies of the edifice, thus implying the existence of a common design ${ }^{15}$. The templon (Fig. 6, 7) has been built at the eastern part between the first and the second pair of blind arches and it is built on a podium, as its counterpart at Vutufou. It

${ }^{10}$ B. MULVANEY, The Beholder as Witness. The Crib at Greccio from the upper church of San Francesco Assisi and Franciscan influence on late medieval art in Italy, in R. COOK (ed.), The Art of the Franciscan order in Italy, Leiden 2005, pl. 1, 3-4.

${ }^{\text {" }}$ M. BORBOUDAKIS, op. cit. (n. 5), p. 73, fig. 19.

${ }^{12}$ P. EPITROPAKIS, op. cit (n. 3), p. 390.

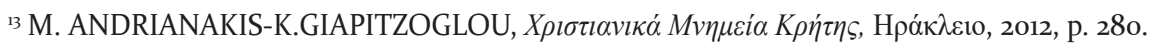

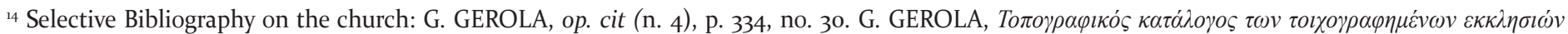

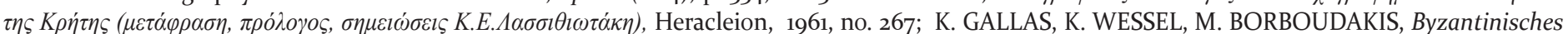

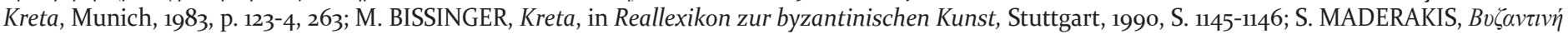
Z Byzantinisches Wandmalerei, Munich, 1995, S. 190-191, Abb. 153. I. SPATHARAKIS, Byzantine Wall Paintings of Crete. Rethymno Province, I. , London, 1999, p. 26-7, 37-8, 41, 69, 238, 250-253, 273, 280, 301, 334. I. SPATHARAKIS Dated Byzantine Wall Paintings of Crete, Leyden, 2001, p. 124-126.

${ }^{15}$ Gallas mistakenly considers the screen as a posterior addition. On the contrary Andrianakis and Giapitzoglou support that the screen was constructed simultaneously with the church. K. GALLAS, Mittel- und Spätbyzantinische Sakralarchitektur der Insel Kreta, Munich, 1983, S.96; M. ANDRIANAKIS-K. GIAPITZOGLOU, op. cit. (n. 13), p. 280. 


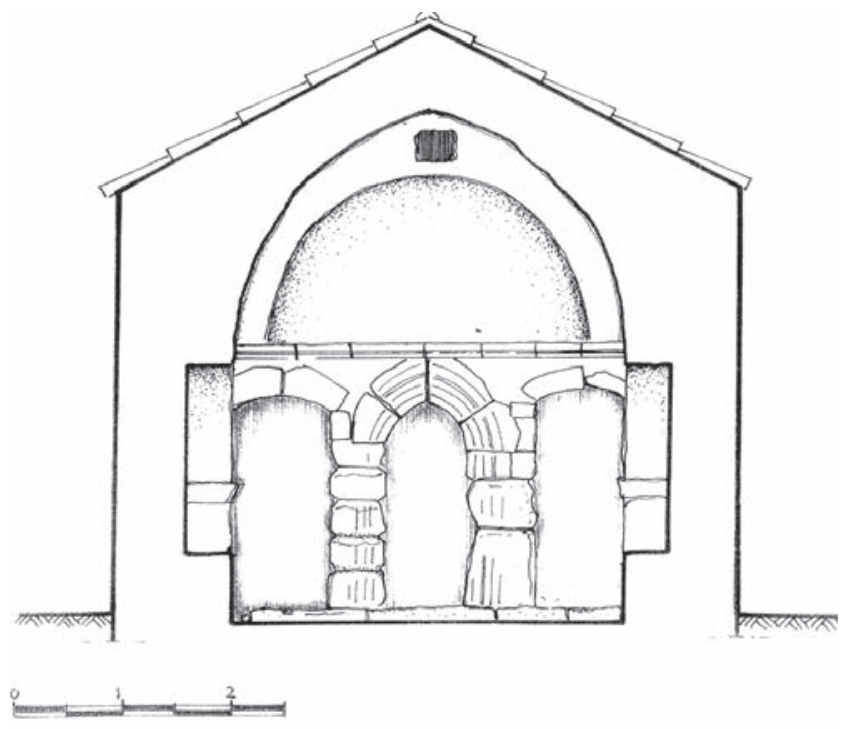

Fig. 8 The templon at Margarites, initial phase (design: G. Perivola).

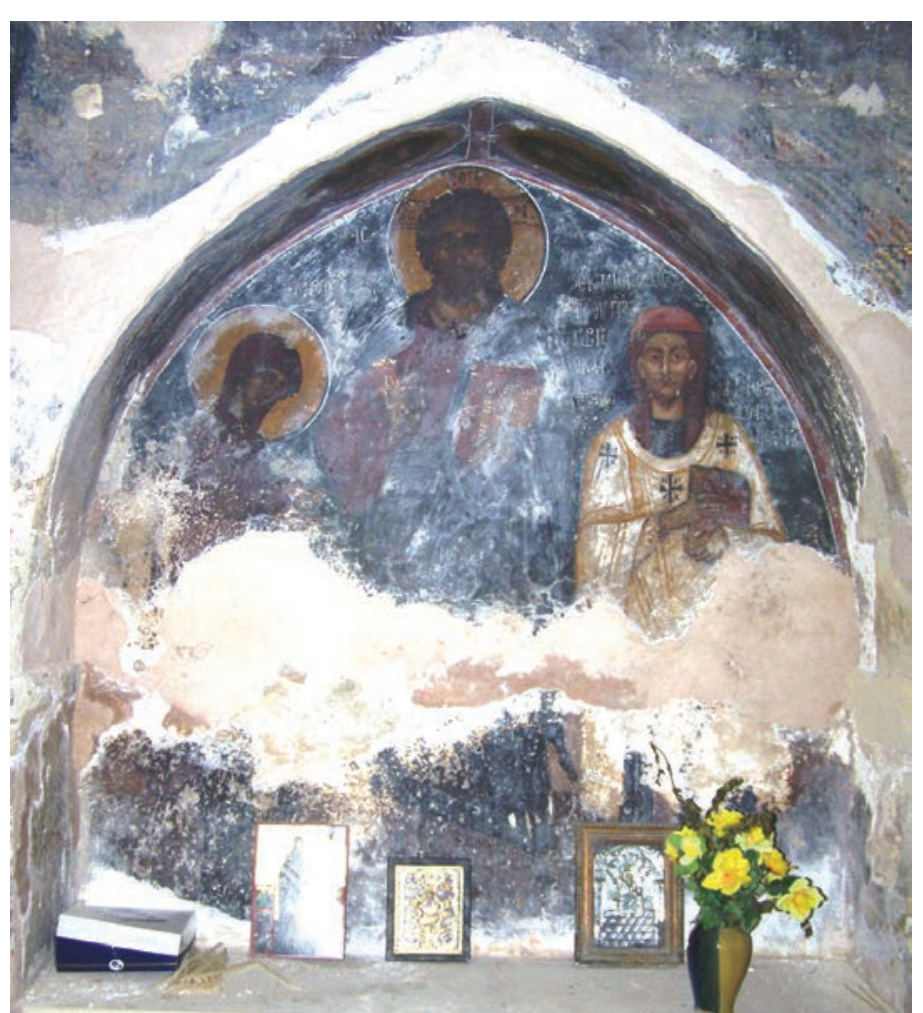

Fig. 10 Fresco depicting Deësis with Georgios Klados, Margarites (author).

consists of a triple arcade supported by piers. The latter are constructed with asymmetrically juxtaposed massive blocks and minimal joints. The central pointed arch (Beautiful Gate) is framed by four ribs crudely carved at the extrados of the piers, whereas its top looks like being suppressed by the superimposed cornice. Two monoliths shape each one of the lateral pointed-segmental arches that spring directly from the wall and reach the central piers. Today the northern opening leads to the "Prothesis" table of the Bema, while the southern one is blocked by a stone slab (o, $92 \mathrm{X} \mathrm{o,} \mathrm{50m.).} \mathrm{The} \mathrm{differ-}$

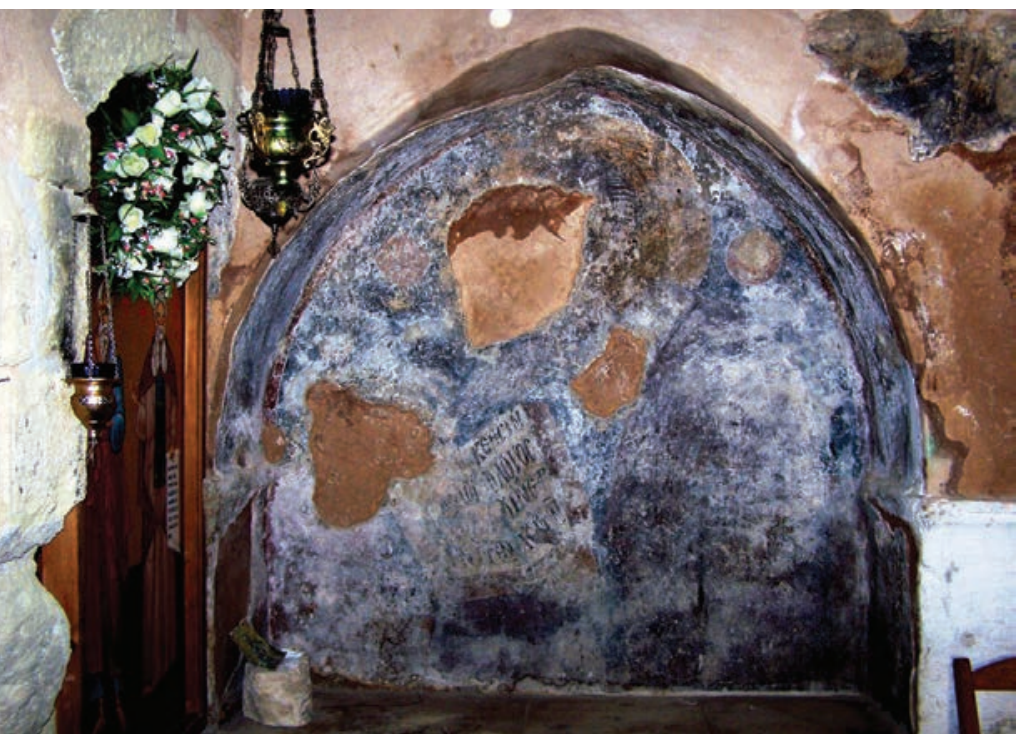

Fig. 9 Fresco depicting the patron Saint St. John the Theologian, Margarites (author).

ence between the materials of the block and the screen, the intentional cutting of the lower part of the southern pier (for the adjustment of the block) and the mural decoration at the soffit and intrado of the southern arch suggest the posterior fitting of the block at the southern arch, which was probably used as an entrance. Thus the initial phase of the screen can be reconstructed as an open triple arcade, decorated with a stone cornice (Fig. 8). This triple arrangement intensifies as in the case of the Vutufou screen the delusive image of a tripartite Bema, which in reality is a single unified bay.

The screen does not have any kind of fresco compositions or portraits, yet its lower part preserves remnants of aniconic decoration. The absence of frescoes from the templon seems to contradict with the usual arrangements of its contemporary masonry screens, which usually displayed icon-like representations of Christ, Virgin or the patron Saint on their front. On the contrary, the Margarites screen is characterized by its openness, suggesting the highly doubtful existence of any frescoes at its initial phase. The screen must be conceived as part of a wider scenographic ensemble that included the frescoes of the neighboring blind arches ${ }^{16}$. At the southern blind arch next to the templon there was depicted the oversized bust of the patron Saint, St. John the Theologian bending towards the templon (Fig. 9). The Saint holds an open Gospel, bearing the verses: "EN APXH HN O $\Lambda$ ОГО $\Sigma$ KAI O $\Lambda$ OГО $\Sigma$ HN ПРО $\Sigma$ TON $\Theta E O N$ KE $\Theta E O N$

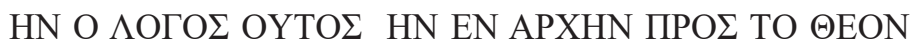
$(I o .1,1)^{17}$. Generally, the portrayal of the patron Saint at the neighboring blind arch of the screen is a phenomenon already traced from the $12^{\text {th }} \mathrm{c}$. (cf. Hagios Nikolaos Kasnitzes at Kastoria $)^{18}$. The oversized depiction of the patron Saint is a frequent arrangement for the Cretan churches of the $14^{\text {th }} \mathrm{c}$. (Hagios Nikolaos Mouri Kissamos, Hagios Nikolaos Mone) suggesting that these frescoes were possibly used as prostration images ${ }^{19}$. At the northern blind arch, symmetrically juxtaposed to the depiction of St. John, there is depicted a peculiar version of Deësis (Fig. 10). The frontal Christ is

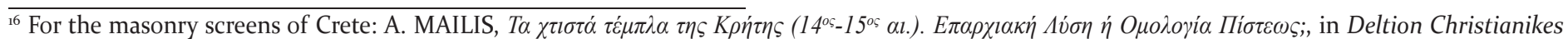
Archeologikes Etaireias, 36, 2015, 111-144.

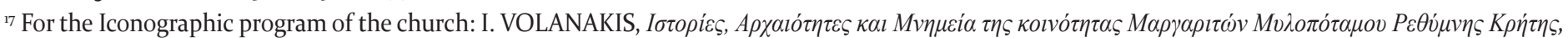
in Nea Christianike Kriti 1999-2000, p. 21-36.

${ }^{18}$ S. GERSTEL, Beholding the Sacred Mysteries. Programs of the Byzantine Sanctuary, Seattle-London, 1999, p. 90.

${ }^{19}$ For the subject: A. MAILIS, op. cit (n. 16), p. 138. Bacci localizes at Cyprus and Italy a group of icons and frescoes whose common feature is their adjustment under an arched frame. M. BACCI, Side Altars and Pro Anima Chapels in the Medieval Mediterranean: Evidence from Cyprus, in J. E. KROESSEN-V.
} 
placed in the middle of the composition. At His left side there is depicted Virgin slightly bowing her head towards her Son and at the right part is to be found the frontal portrayal of a bearded Orthodox priest in full regalia (sticharion, epitrachelion and felonion). The inscription above says:

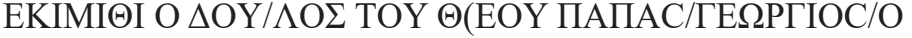
$\mathrm{K} \Lambda \mathrm{A} \Delta \mathrm{OC} / \mathrm{ET}(\mathrm{EI}) \mathrm{CT} \Omega \varsigma^{\prime} \mathrm{A}^{\prime} \mathrm{MI}(\mathrm{NI}) \Phi \mathrm{PEY} / \mathrm{BOYAPIO} / \mathrm{H} \Sigma \mathrm{TEC}$ $\mathrm{KB}^{\prime}$. It informs us that the priest and possible donor of the church "the servant of God" Georgios Clados died on the 22th February $1383^{20}$. The composition is individual ${ }^{21}$. It is surely related with the known subject of Virgin's intercession on behalf of the deceased ${ }^{22}$, yet the frontal position of the priest as well as his equal height with the Virgin aim more to the exaltation of the mortal's personality and less to his humbleness towards Christ as one would expect for this genre of compositions. Conceptual analogies can be traced at: 1) the Deësis at the cell of Hagios Neophytos in Cyprus (1183), where the deceased Neophytos is depicted kneeling in the forefront of the composition ${ }^{23}, 2$ ) the NW. chapel of the Afendiko-Odegetria church in Mystras (ca. 1322) that was used the burial place for the abbot Pachomios. There, choirs of Prophets, Apostles, Patriarchs, Martyrs and Saints participate in an expanded procession towards Christ, intermediating for the rest of the deceased abbot's soul, according to the funerary inscription ${ }^{24}$. These two parallels indirectly underline the significance of the mortal's personality by using sophisticated iconographic schemes. On the contrary, the Cretan composition sends a direct message. Its thematic core relies on the local iconographical tradition, which often dictates the micrographic depiction of the donors next to the main prostration image of the church, f.e. at the church of Archangel Michael at Sarakena ( $1^{\text {st }}$ half of the $14^{\text {th }}$ c. $)^{25}$. Yet the dimensions of Clados' stature display an unusual self-confidence, which originates either from his local family status ${ }^{26}$, or his ecclesiastical authority. The latter could be also underlined by the construction of a monumental screen ${ }^{27}$, which imitates in a crude provincial manner a more elaborate model of possible Latin origin. It is noteworthy that western influences such as the apsis synthronon ${ }^{28}$ or secondary details of the fresco decoration (scene of Lamentation) ${ }^{29}$ are also traced in the same church.

The third example is found at the church of Hagios Nikolaos Chostos, near Argyroupoli, Rethymno. The settlement, which was the seat of the local bishopric, displays a considerable quantity of churches, which suggest its prosperity during the medieval period ${ }^{30}$. The church of Hagios Nikolaos lies on a mountainous and inaccessible site nearby the river Mouselas ${ }^{31}$. Already from the $11^{\text {th }} \mathrm{c}$. the region was connected with the neighboring convent of Myriokefala that was founded by the popular local saint Hagios Ioannis Xenos $^{32}$. The church was inserted in a large cave and it was hidden by a huge wall with a miniscule entrance, giving the impression of a fortification. Outside the wall there were found remnants of rooms as well as cisterns suggesting that

M. SCHMIDT (eds.), The Altar and its Environment (1150-1400), Bruxelles, 2010, p. 23. About the subject of the Lunette-shaped Panels: V. M. SCHMIDT, The Lunette-Shaped Panel and some characteristics of Panel Painting, in V. M. SCHMIDT (ed.), Italian Panel Painting of the Duecento and Trecento, Washington, 2003, p. 395-425.

${ }^{20}$ I. VOLANAKIS, op. cit. (n. 17), p. 32-3.

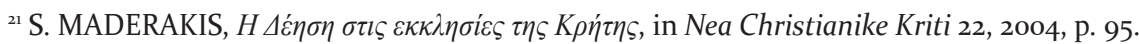

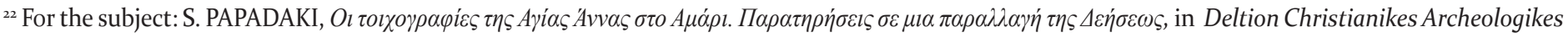
Etaireias, 7, 1973-4, p. 31-57.

${ }_{23}$ C. MANGO-E.J.W. HAWKINS, The Hermitage of St. Neophytos and its Wall paintings, Dumbarton Oaks Papers 20, 1966, fig. 105-7.

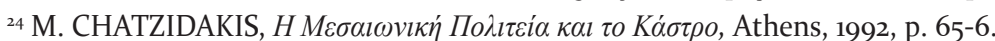

${ }^{25}$ A. MAILIS, op. cit. (n. 16), fig, 13.

${ }^{26}$ There are different versions for the genealogy of the Clados family. A first theory considers that it originates from the general Minas Cladourios, who allegedly accompanied the representative of 12 Byzantine aristocratic families from Constantinople to Crete (1092). A second theory considers that the

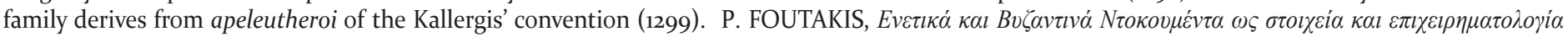

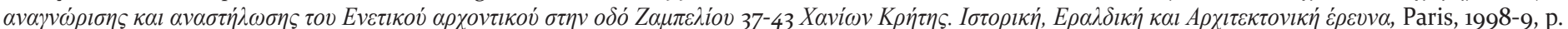
25 (unpublished study from the archives of the Ephoreia Archaeotiton Chanion, The name Clados refers to three priests that are included in the cadastre of churches and convents of the Chania region (1637): 230. C. papa Giorgila Clada dal cl. Caridi et da in nota sua di S. Zorzi con cur di anime ma senzo alcune sorte de intrada. 236. C. papa Manoli Clada dal Cl. Vamo et da in nota offitior la chiesa di S.Zuanne Theologo con cura d'anime et intrada. 248. C. papa Giorgi

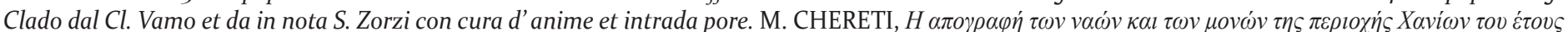
1637, in Epeteris Etaireias Byzantinon Spoudon, 36, 1968, p. 362-3.

${ }^{27}$ For the relation between the existence of templon and the clerical prestige: S. GERSTEL, An alternate view of the Late Byzantine Sanctuary, in S. GERSTEL (ed.), Thresholds of the Sacred: Architectural, Art Historical, Liturgical and Theological Perspective on Religious Screens, East and West, Washington, 2006, p. 136.

${ }^{28}$ The existence of synthronon along with a vertical apsis at Patso is interpreted by Gratziou as a Latin influence. O. GRATZIOU, op. cit. (n. 1), p. 247. On

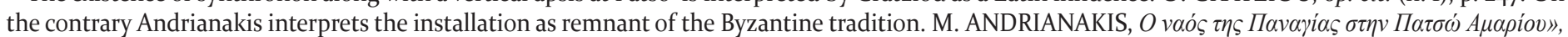

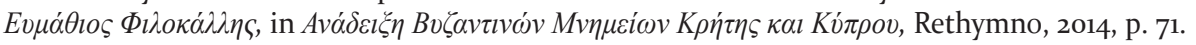

${ }^{29} \mathrm{P}$. Fiolitaki supports that the fresco of lamentation at the church of Hagios Ioannis is influenced by the religious imagery and beliefs of the $13^{\text {th }} \mathrm{c}$. Italy, pos-

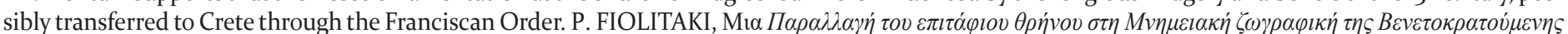

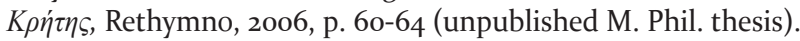

${ }^{30}$ In the settlement of Argyroupoli lies the church of the Virgin Barozzi, which is connected with the local noble family of Barozzi, who possessed large feuds at the region. At the SW. part of the settlement lies the fresco painted church of Hagios Nikolaos $\left(14^{\text {th }}\right.$. c.). Nearby the shores of river Mouselas it is localized the church of Hagia Kyriaki (with $11^{\text {th }} / 13^{\text {th }}$ c. frescoes). For the Barozzi church: G. GEROLA, op. cit. (n. 2), tav. 6. M. ANDRIANAKIS, H $\alpha \rho \chi I \tau \varepsilon k \tau o v i k \eta ́$

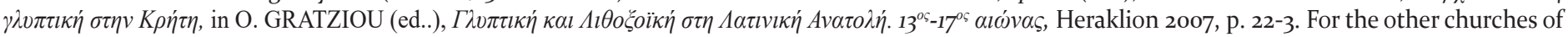
the settlement: M. ANDRIANAKIS-K.GIAPITZOGLOU , op. cit. (n. 13), p. 262.

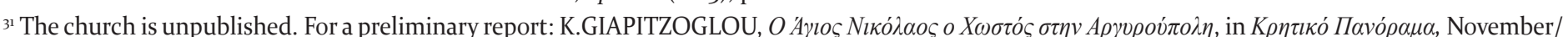

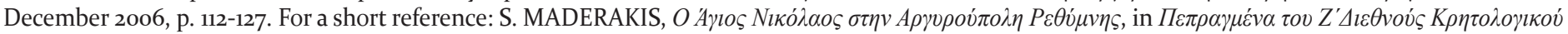

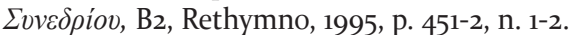

$3^{2}$ K.GIAPITZOGLOU, op. cit. (n. 31). 


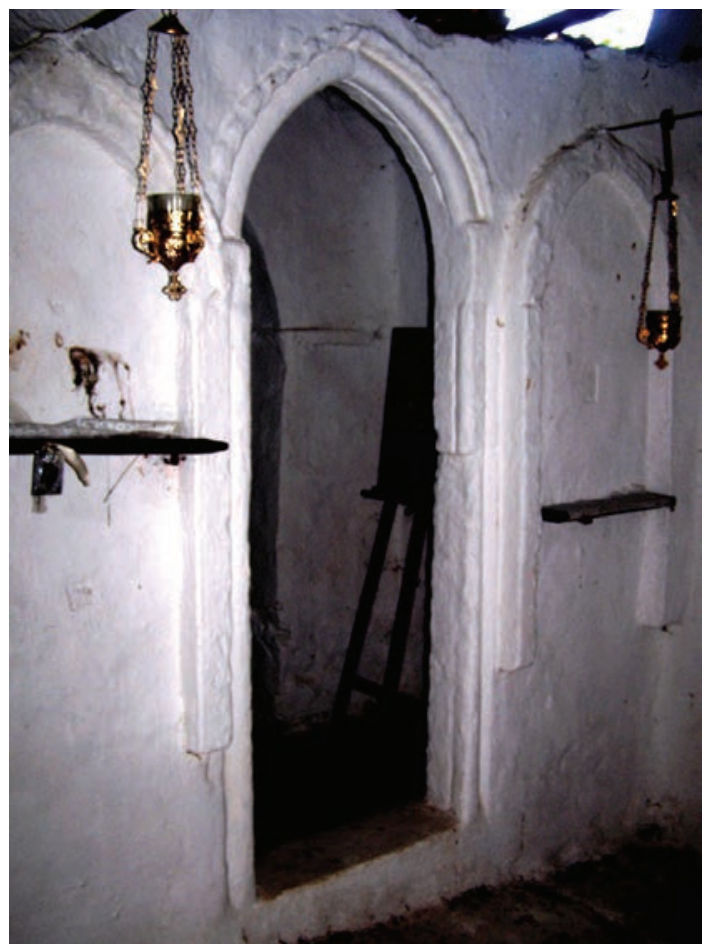

Fig. 11 The templon at Hagios Nikolaos Chostos, Argyroypoli (author).

the church probably served the needs of a small convent, possible dependent upon a larger monastic foundation.

The church is a miniscule edifice $\left(7 \mathrm{X}_{3} \mathrm{~m}\right.$.), partially rock cut (northern wall and roof). A western narthex has been added possibly in the $19^{\text {th }} \mathrm{c}$. Its screen is covered with white plaster and it has been probable subjected to modifications (Fig. 11, 12). Its dimensions (2,30m. width. 2,65m. height) resemble the previous two examples. Today, the templon can be described as a solid wall pierced by a central entrance (Beautiful Gate) and two lateral blind arches. The pointed arch of the Beautiful Gate is framed with one rib, corniced with a dentiled frieze, similar with the decoration of the two lateral ones. This kind of ornamentation displays a simplified version of the so-called Venetian Gothic Style, as it is observed in many Cretan churches of the $15^{\text {th }} \mathrm{c} .{ }^{33}$. It is noteworthy that the upper part of the Beautiful Gate posts was disrupted, possibly for the posterior adjustment of wooden Bema doors. Additionally the posts of the blind arch seem to terminate ca. $\mathrm{o}, 50 \mathrm{~m}$. above the floor, equally suggesting a remodeling of the installation. The morphological resemblance between the screen and the main entrance portal suggest simultaneous construction, which according to architectural parallels such as Hagios Georgios Emparos $(1435 / 6)$ could be dated in the first half of the $15^{\text {th }}$ c. ${ }^{34}$.

Sections at the walls of the church suggested the absence of any frescoes from its western one ${ }^{35}$. At the southern wall, next to the screen, there has been found an oversized head of a bearded Saint (possibly Nicolas) surrounded with a

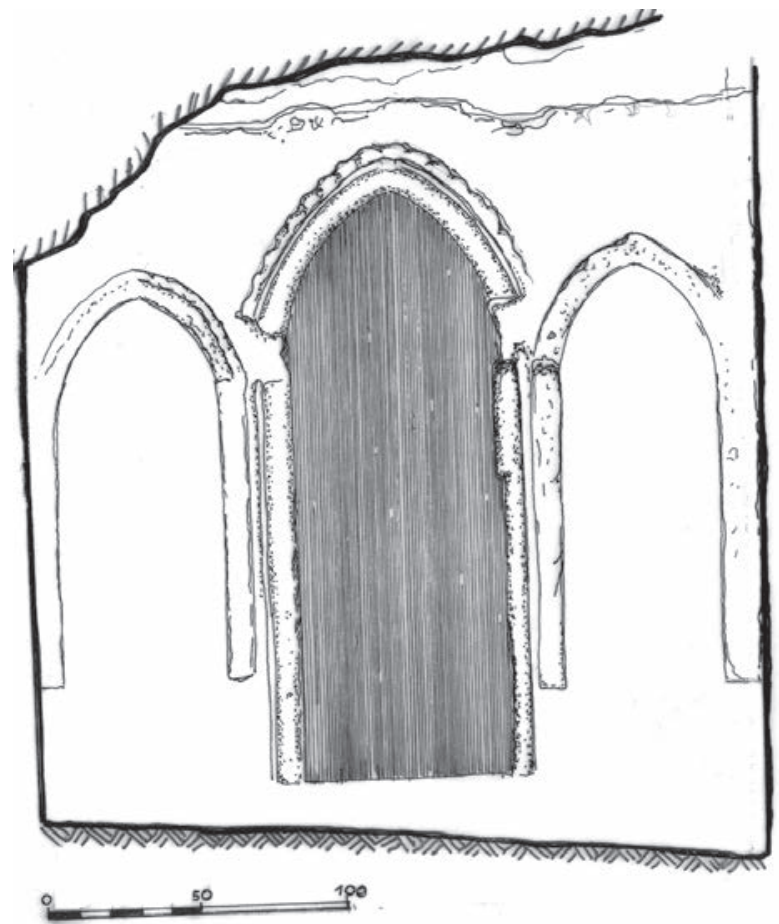

Fig. 12 The templon at Argyroupoli (design: G. Perivola).

sculpted nimbus ${ }^{36}$. The latter feature accompanies the frescoes of the patron Saints in a diminished number of Cretan churches $^{37}$, thus implying that the specific oversized fresco functioned as a prostration image, just as its counterpart image of St. John at the church of Margarites. Unfortunately the posterior modifications of the screen do not allow us to define the initial shape of the templon, which could be either a solid wall or an open installation. The general morphological features allow its date in the early $15^{\text {th }} \mathrm{c}$.

The planning of the above mentioned templa is unusual in comparison with the standard arrangements of their contemporary masonry screens ${ }^{38}$. The height of this group ranges from $2,45 \mathrm{~m}$. to $2,65 \mathrm{~m}$., significantly elevated in comparison with the average masonry templa $(1,80-1,90 m .)^{39}$. They are formed with a triple arcade, either with semicircular arches (Vutufou) or with pointed ones (St. John the Theologian, Hagios Nikolaos Chostos). They display a distinctive openness of design (with the possible exception of Hagios Nikolaos, where the initial arrangement remains unknown). Their construction technique relies heavily on the use of raised stone blocks with minimal joints, thus giving the impression of a sculpture. On the contrary masonry screens are constructed with rubble stonework covered with frescoes and pierced with one entrance. Seeking morphological parallels for this individual group, one could possibly mark a faint analogy with the semicircular arch of the northern surviving part of the masonry screen at the church of Kaloritissa in $\operatorname{Naxos}^{40}$ or

\footnotetext{
33 For the use of term on the Cretan monuments: M. BORBOUDAKIS, op. cit. (n.5), 67.

${ }^{34}$ Ibidem, p. 81.

35 K.GIAPITZOGLOU, op. cit. (n. 31), p. 127.

${ }^{36}$ For the western origin of the technique: S. MADERAKIS , op. cit. (n. 31), p. 451 n. 1

${ }^{37}$ See the unpublished examples of the Archangels Michael and Gabriel in the church of Archangel Michael at Episkopi Pediadas, as well as the Prostration image of Christ in the church of Transformation at Myrthios in Rethymno.

${ }^{38}$ For an introduction to the Cretan masonry screens: A. MAILIS, op. cit. (n. 16), p. 111-144.

39 Ibidem, p. 138.

${ }^{40}$ M. PANAGIOTIDI, L'église rupestre de la nativité dans l' île de Naxos. Ses peintures Primitives, in Cahiers Archéologiques 23, 1974, p. 108, fig. 2.
} 
the templon that was posterior constructed at the middle Byzantine church of Ai Kyr Giannis Alikianos near Chania, $\mathrm{Crete}^{41}$. Yet these similarities are reduced to secondary details and do not refer either to a common morphology or construction technique.

The three Cretan screens seem to break with the middle Byzantine tradition of templa consisted of chancel slabs, colonnettes and friezes, thus referring to a different architectural prototype. The question remaining is which could be the origin of this model? At this point it would be useful to cite $\mathrm{S}$. Gerstel's case study. The scholar suggests a possible influence of Latin palae d' altare to the Orthodox double painted masonry screens as a product of Western-Byzantine cultural exchanges especially in the Latin occupied Peloponnesus and the insular region. Furthermore she stresses out the necessity of an additional research concerning the connection between Orthodox screens and Latin choir partitions ${ }^{42}$. Although one could support that sometimes the presence of the Orthodox screen itself in Latin occupied territories (such as Crete) is used more as a symbol of religious opposition than that of cultural osmosis ${ }^{43}$, Gerstel's suggestion could be plausible for the interpretation of the individual characteristics of this specific Cretan group.

The choir partitions are known to us with different names in dependence with the country they are found: Lettner in Germany, Jubés in France, Rood Screens in England, Tra- mezzi in Italy. Although their research is negligible in Greece due to the lack of material evidence ${ }^{44}$, there is a vast central European literature mainly for the numerous German Lettner still existent ${ }^{45}$. The Italian tramezzi, which concern us directly, came up to prominence especially through Marcia B. Hall's pioneering studies in the $70 \mathrm{~s}^{46}$, while significant essays on the topic are published from 2000 onwards ${ }^{47}$. The primary function of these partitions is to isolate the choir and the High altar from the area of the laity, thus arranging eine Kirche in der Kirche, as Doberer remarks ${ }^{48}$. They are considered as standard furnishings of monastic churches, cathedrals and occasionally parish churches ${ }^{49}$, chronologically ranging from the $11^{\text {th }} \mathrm{c}$. to the $16^{\text {th }} \mathrm{c} .5^{50}$. The main reason for their gradual abolishment relates to the Trent Council (1550-1565) decrees, which disfavored the division between clergy and laity and promoted the energetic participation of the laity in the ceremonial activities, according to the spirit of the Counter-Reformation ${ }^{51}$. Although the decrees do not refer directly to these partitions, they contributed to the decline of their construction and their successive removal or even destruction ${ }^{52}$. Such demolitions occurred mainly in Italy, while countries in loose connection with the Papal jurisdiction, such as England or Germany kept intact their anterior furnishings ${ }^{33}$.

The function of the partitions and their superimposed exedras is connected with the fixation of the Rood, the

${ }^{41}$ The screen survived up to the early $20^{\text {th }} \mathrm{c}$. and it was photographed by Gerola.

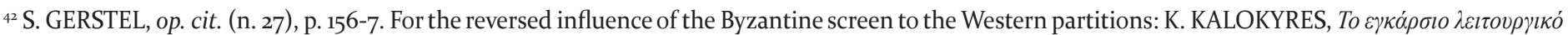

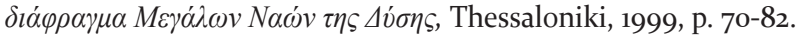

${ }^{43}$ A. MAILIS, op. cit. (n. 16), p. 111-144

${ }^{44}$ K. KALOKYRES, op. cit. (n. 42 ).

${ }^{45}$ Selective bibliography: E. DOBERER, Der Lettner. Seine Bedeutung und Geschichte, in Mitteilungen der Gesellschaft für vergleichende Kunstforschung in Wien 2, 1956, S. 117-122 (a pioneering article with innovative terminology); M. UNTERMANN, Chorschranken und Lettner in südwestlichen Stadtkirchen-Beobachtungen zu einer Typologie mittelalterlichen Pfarrkirche, in Architektur Geschichten. Festschrift für Günther Binding, Köln, 1996, S. 73-90. H. MAGIRIUS, Schranken und Lettner in den Kirchen der Mönche in Mittelalter, in T. KUNZ-D. SCHUMANN (eds), Werk und Rezeption. Architektur und ihre Ausstattung. Ernst Badstübner zum 8o. Geburtstag. Studien sur Bachsteinarchitektur 10, Berlin, 2011, S. 116-130. R. PIEPER, Von der Uneinheit des Kirchenraumes: Lettner, in R. PIEPER (ed.), Kunst von den Anfängen bis zur Gegenwart, Paderborn-München-Wien-Zürich, 2012, S. 355-366. For the central European partitions: J. JUNG, op. cit. (n. 7), p. 622-657; EAD., Seeing Through Screens: The Gothic Choir Enclosure as Frame, in S. GERSTEL (ed.), Thresholds of the Sacred: Architectural, Art Historical, Liturgical and Theological Perspectives on religious screens, East and West, Washington, 2006, p. 185-213; EAD., The Gothic Screen. Space, Sculpture and Community in the Cathedrals of France and Germany ca. 1200-1400, Cambridge, 2013.

${ }^{46}$ M. B. HALL, The Ponte in S. Maria Novelae. The problem of the Rood Screen in Italy, in Journal of the Warburg und Courtauld Institute 37, 1974, p. 157-173. EAD., The Tramezzo in Santa Croce, reconstructed, in Art Bulletin 56, 1974, p. 325-341. EAD., The Italian Rood Screen: "Some Implications for Liturgy and Function, in S. Bertelli-G. Ramakus (eds.), Studies presented to Myron Gillmore, Florence 1978, 213-218. EAD., Renovation and Counter-Reformation: Vasari and Duke Cosimo in Santa Maria Novella and Santa Groce, Oxford, 1979. For a re-appraisal of her own work: EAD.,The Tramezzo in the Italian Renaissance, Revisited, in S. GERSTEL (ed.), Thresholds of the Sacred:Architectural, Art Historical, Liturgical and Theological Perspectives on religious screens, East and West, Washington, 2006, p. 215-232.

${ }^{47}$ For Northern Italy: T. CREISSEN, Les clotures de Chor des èglises d' Italie a l' époque romane: ètat de la question et perspectives, in Hortus Artium Medievalium 5, 1999, p. 169-181. D. COOPER, Franciscan Choir enclosures and the Function of Double-sided Altarpieces in Pre-Tridentine Umbria, in Journal of the Warburg und Courtauld Institute 64, 2001, p. 1-54; ID., Access all areas? Spatial divides in the Medieval Churches of Late Medieval Tuscany, in F. ANDREWS (ed.). Ritual and Space in the Middle Ages: Proceedings of the 2009 Harlaxton Symposium. Harlaxton Medieval Studies 21, Donington, 2011, P. 90-107. For Venice: M. MEROTTO-GHEDINI, Il tramezzo nella chiesa dei Santo Giovanni e Paolo a Venezia, in G. LORENZONI et al. (eds), De lapidis scritti di Storia dell' Arte per Giovanni Lorenzoni, Padua, 2002, p. 257-262; P. MODESTI, I cori nelle chiese veneziane e la visita apostolica del 1591. Il "barco" di Santa Maria della Carità, in Arte Veneta 59, 2002, p. 38-65; EAD., Recinsioni con colonne nelle chiese Veneziane. Tradizioni, Revival, Sopravvivenze, in J. Stabenow, Lo Spazio e il Culto.Relazioni tra edificio ecclesiale e uso liturgico dal XV al XVI secolo, Venice, 2006, p. 181-208; EAD., I cori nelle chiese parrochiali veneziane fra età umanistica e riforma tridentina, in S. FROMMEL (ed.), La Place du Chœr. Architecture et Liturgie du Moyen Âge aux Temps modernes, Paris, 2012, p. 141-155. ${ }^{48}$ E. DOBERER, op. cit. (n. 45), S. 117.

${ }^{49}$ H. MAGIRIUS, op. cit. (n. 45), S. 116. Hall believes that the Italian tramezzi are exclusively located in monastic churches, M. B. HALL, op. cit. (n. 46 ), p. 216. ${ }^{50}$ See the reconstructed Tramezzo over the crypt of San Miniato, Fiesole, Florence ( $11^{\text {th }}$ c.). R. TOMAN, Die Kunst der Romanik, Architektur, Skulptur, Malerei, Cologne, 2004, p. 93.

${ }^{51}$ M. B. HALL, op. cit. (n. 46), p. 158.

${ }^{2}$ M. B. HALL, op. cit. (n. 46), p. 220. Most characteristic for the application of Trent decrees was the visit of the Papal representatives at Venice in 1581. These representatives recorded the Venetian choirs and decided if they fulfilled the Trent requirements. MODESTI, op. cit. (n. 47), p. 38-65.

${ }_{53}$ M. B. HALL, op. cit. (n. 46), p. 158. 


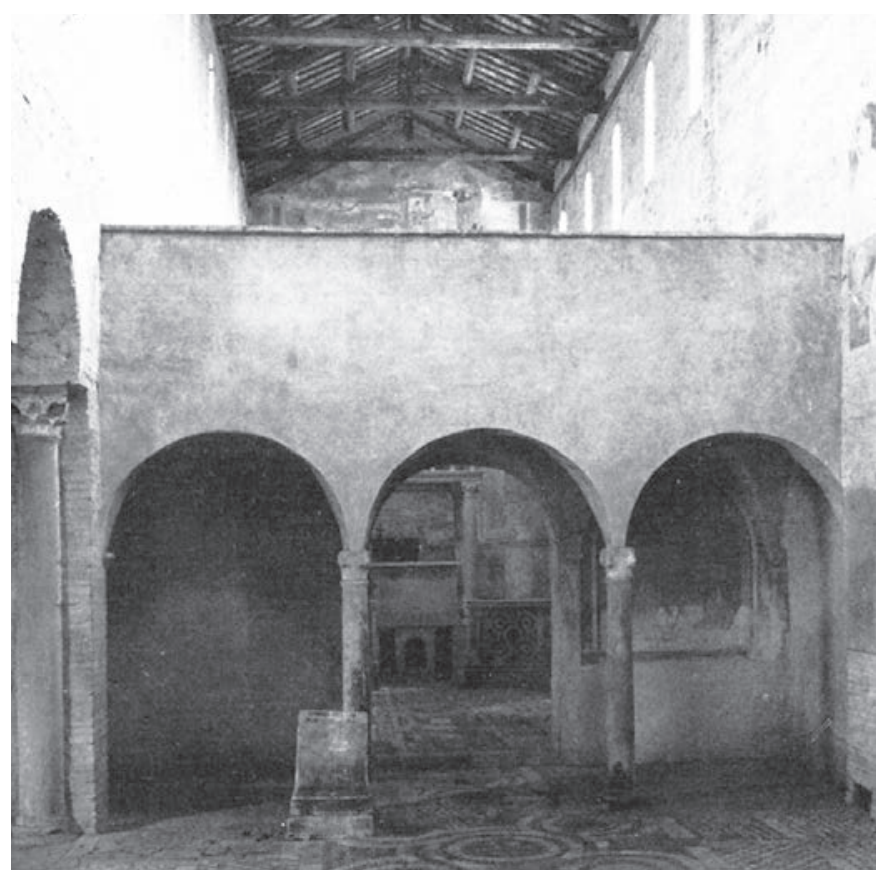

Fig. 13 The tramezzo at Sant Andrea in Flumine, Ponzano Romano (I. HUECK, Der Lettner der Unterkirche von San Fransesco in Assisi, in Mitteilungen des Kunsthistorischen Institutes in Florenz 28, 1984, Abb. 5, S. 180).

reading of the Gospel, the preaching and occasionally with theatrical enactments of religious character ${ }^{54}$. Their position in the church depends on the number of the clerics, thus in small churches the partitions are restricted at the eastern part of the edifice but in large abbeys they are expanded up to the middle of the nave ${ }^{55}$. Although these installations are introduced in the ecclesiastical architecture as a means of separation between the clergy and the congregation ${ }^{56}$, both visual imagery and written sources of the period imply that the male laity was able to enter the barrier and approach the High altar ${ }^{57}$. We also know that the choir itself was used occasionally for the validation of legal acts, including the presence of women ${ }^{5}$. Consequently the function of the partitions was not defined as strictly as their Byzantine counterparts (templa).

These partitions display an expanded typology, although from the $13^{\text {th }} \mathrm{c}$. onwards the type of Hallenlettner predominates. This category included the superimposition of a raised platform over an eastern solid wall (usually pierced by one entrance) and a western open arcade (with 3, 5, 7 or 9 arches).

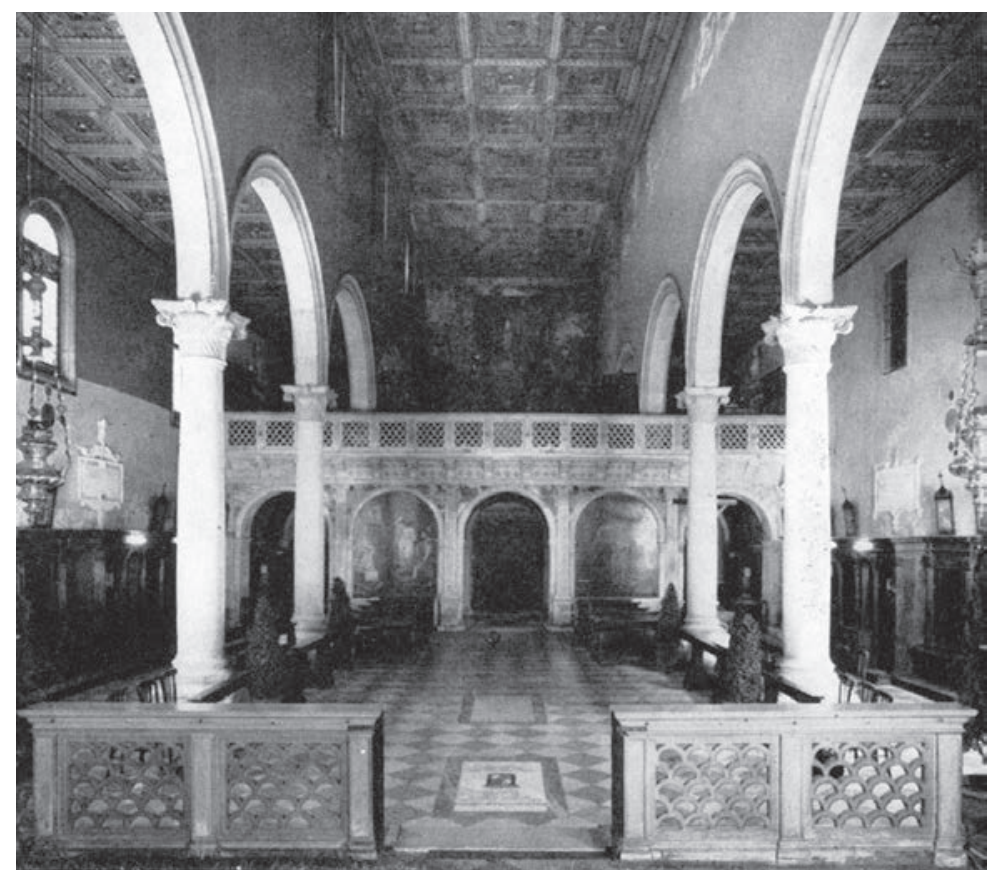

Fig. 14 The tramezzo at San Michelle in Isola, Venice (M. B. HALL, The Ponte in S. Maria Novelae. The problem of the Rood Screen in Italy, in Journal of the Warburg und Courtauld Institute 37, 1974, pl. 38b).

In the between space there is created a portico covered with a series of groin vaults ${ }^{59}$. It is noteworthy that a variation of this type is particularly popular in Venice, where it is called coro aperto ${ }^{60}$. The Cretan screens under discussion display morphological and constructional analogies with façades of the Hallenlettner type, mostly of Italian origin. The most elaborate example of our group is traced at Vutufou. As it has been already noted, its painted decoration resembles those of the $13^{\text {th }} \mathrm{c}$. Italian edifices as they are depicted at Giotto's frescoes. The motif of the triple semicircular/segmental arches is popular for the façades of $12^{\text {th }} / 13^{\text {th }} \mathrm{c}$. German Lettner, such as Maulbronn or Wechselburg ${ }^{61}$. Yet the closest parallel is traced at the tramezzo of Sant Andrea in Flumine, Ponzano Romano (Fig. 13), which was constructed during Duecento ${ }^{62}$. The specific form is also well-liked for the Italian and specifically the Venetian tramezzi during the next centuries such as San Rocco, Vicenza $\left(15^{\text {th }} \mathrm{c} \text {. }\right)^{63}$, San Michelle in Isola, Venice (1469) (with five arches) (Fig. $14)^{64}$ and San Nicolo dei Mendicoli, Venice $\left(16^{\text {th }}\right.$ c.), where the partition is shaped as an open single wall construction

\footnotetext{
54 E. DOBERER, op. cit. (n. 45), S. 118. M. B. HALL, op. cit. (n. 46), p. 222-223. 55 J. JUNG, op. cit. (n. 7), p. 625. H. MAGIRIUS, op. cit. (n. 45), S. 116-117.

${ }^{56}$ See the specific order of the Dominicans (1249): Intermedia que sunt in ecclesiis nostris inter seculares et fratres sic disponantur ubique per priores quod fratres egredientes et ingredients de choro non possint videri a secularibus, vel videre eosdem. B.M. REICHERT-F.A. FRÜWIRTH (eds.), Acta Capitulorum generalium Ordinis Praedicatorum, Rome-Stuttgart, 1898, p. 47: 10-14. For the use of partition for the separation of sexes: D. COOPER, op. cit. (n. 47), p. 47. ${ }^{57}$ See Giotto's Christmas miracle at Greccio (before1297). For the fresco and the sources: J. JUNG, op. cit. (n. 7), p. 628.

${ }^{8}$ D. COOPER, op. cit. (n. 47), p. 100-101.

59 E. DOBERER, op. cit. (n. 45), S. 119. J. JUNG, op. cit. (n. 7), p. 625.

${ }^{60}$ MODESTI, op. cit. (n. 47), p . 45.

${ }^{61}$ See the Lettner of Cistercian Church in Maulbronn (1170/80), of the Cathedral at Wechselburg (ca. 1230). H. MAGIRIUS, op. cit. (n. 45), S. 124, Abb. 3, 7.

${ }^{62}$ I. HUECK, Der Lettner der Unterkirche von San Francesco in Assisi, in Mitteilungen des Kunsthistorischen Institutes in Florenz 28, 1984, S. 178, Abb. 5, 180. For the church: S. CANCELLIERI (ed.), Il complesso monumentale di Sant' Andrea in flumine presso Ponzano Romano, Rome, 2007.

${ }_{63}$ M. B. HALL, op. cit. (n. 46), p. 171.

${ }^{64}$ Hall and Modesti support the dependence of the specific Tramezzo from the anterior Gothic tradition. M. B. HALL, op. cit. (n. 46), p. 170; MODESTI, op. cit. (n. 47), p. 49.
} 
(pergola), possibly under the influence of the Trent decrees $^{65}$. The slight projection of the engaged piers at the Vutufou Screen bears a resemblance to the architectural solutions of the tramezzi at Vezzolano $\left(13^{\text {th }} \text { c.) (Fig. } 15\right)^{66}$ and San Rocco, Vicenza $\left(15^{\text {th }}\right.$ c.), where the lateral supporters are designed either as engaged columns or piers, thus giving the impression that the arches spring directly from the walls (Fig. 16). Similar remarks could be ascribed for the two screens of the Rethymno district. The pointed entrance of the Margarites templon is the commonest pattern for the Gothic tramezzi. It displays a minor affinity with the tramezzo at Vezzolano, although the Cretan example undoubtedly reveals a crude provincial character. It is also noteworthy that the arches of the Margarites Templon spring directly from the walls without the mediation of corbels or piers as it is customary for the Byzantine churches of the island. The prompt similarity of this technique with the counterpart arrangement of the arches at the tramezzo at St. Andrea in Flumine $\left(13^{\text {th }} \mathrm{c}\right.$.), offers a strong argument for its western origin. Additionally, the screen of Hagios Nikolaos Chostos seems like a re-editing of the central idea of the former templon, adjusted to the $15^{\text {th }}$ c. taste. Although it is too tentative to say so, due to the heavily modified condition of the screen today, it bears a strong morphological resemblance with the Lettner of the cathedral of St. Valeria in Sitten, Switzerland (ca. 1290) ${ }^{67}$ (Fig. 17).

On the other hand our screens also exhibit differences with the tramezzi. The Cretan builders use piers as supporters instead of the elegant columns that are used in Italy. Yet the $15^{\text {th }} \mathrm{c}$. of San Michelle in Isola, where the arches are supported by piers with engaged columns ${ }^{68}$, suggests that the specific solution is not unknown for Italy as well. Additionally the Cretan screens are not formed as deep constructions. They are simple/open partitions completed with a cornice. There are not any intermediate corridors, superimposed platforms, or slabs, since the Cretan installations serve the cultic needs of the Orthodox Liturgy, where a plain divider would be sufficient enough. It seems that the specific group incorporates particular elements from the Western partitions such as the high dimensions, the continual arcades and the monumentality, subsequently adjusting them to the Orthodox needs. Consequently, one could suggest that these architectural patterns are transferred in the same way that western iconographic schemes travel and fuse in the Byzantine painting. Through this "transfer" concept, we can interpret certain peculiar arrangements of these templa, such as their triple arrangement, that gives the delusive image of a tripartite sanctuary. In the functional reality of the churches at Vutufou and Margarites the central "Beautiful Gate" and the northern entrance are the sole openings with substantial use for the ceremonial rites of the "Little" and the "Great" Entrances. The

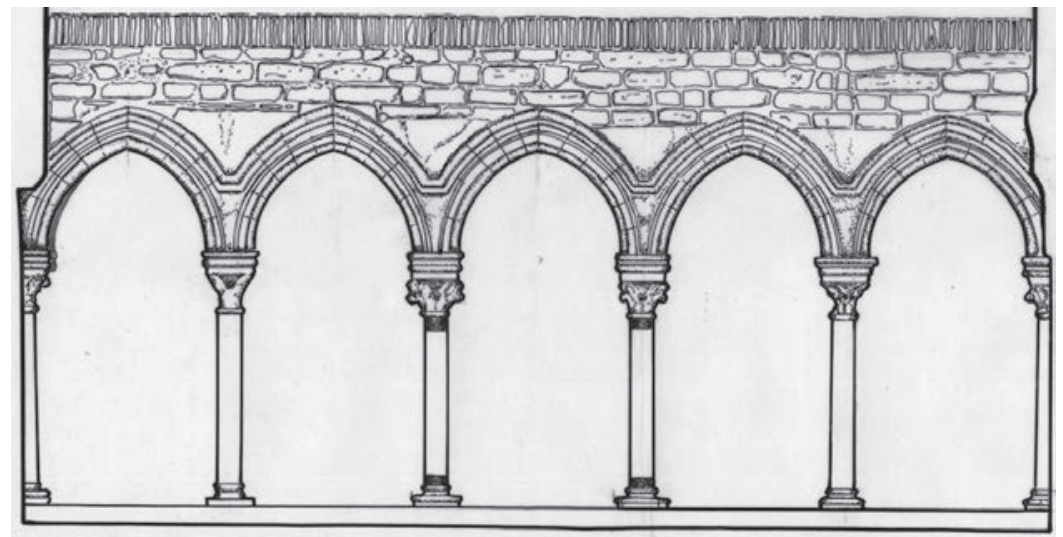

Fig. 15 The tramezzo at Vezzolano (rework of the original plan by F. Delmastro, http://www.osservatoriodelpaesaggio.org/AZIONI\%20svolte/2007/Convegno\%20 Romanico\%20(Vezzolano\%2029\%2009\%2007)/Salerno\%20Paola\%20e\%20 Delmastro\%20Fernando.htm)

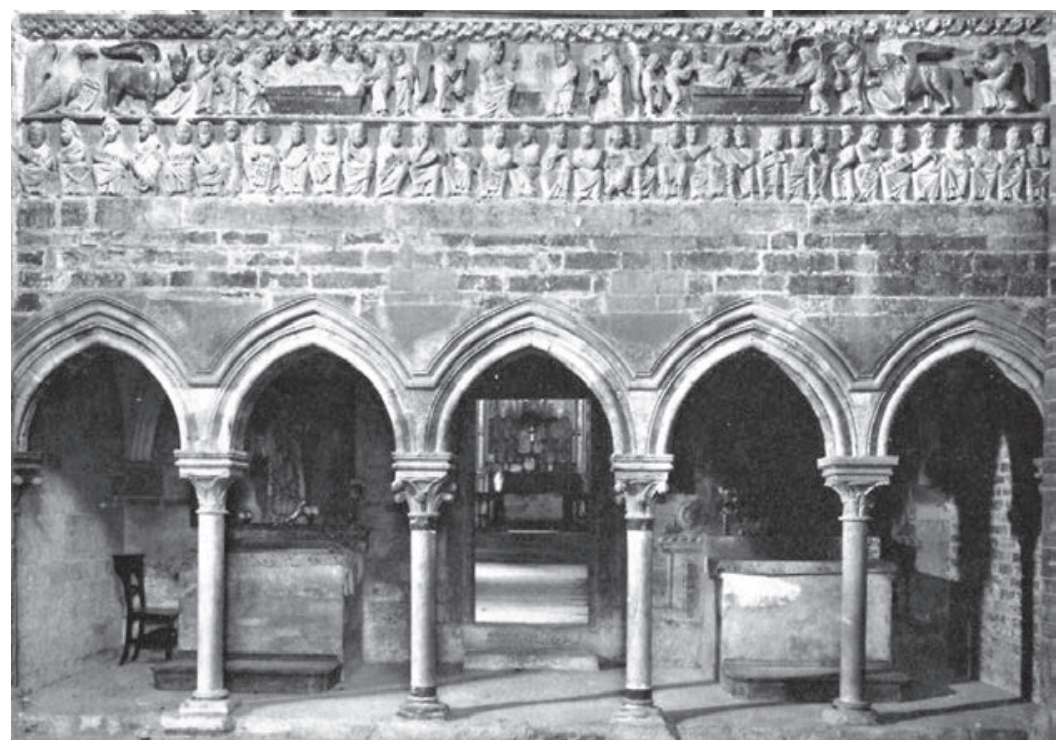

Fig. 16 The tramezzo at Vezzolano (M. B. HALL, The Tramezzo in Santa Croce, reconstructed, in Art Bulletin 56, 1974, fig. 20, p. 335).

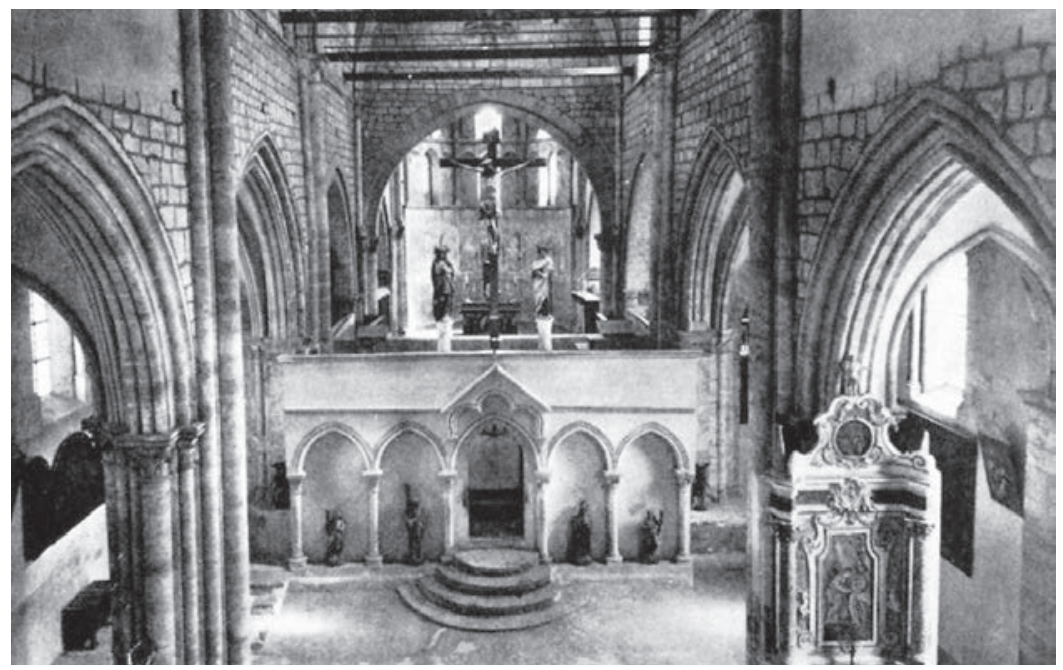

Fig. 17 The Lettner at St. Valeria In Sitten, Switzerland (M. B. HALL, The Ponte in S. Maria Novelae. The problem of the Rood Screen in Italy, in Journal of the Warburg und Courtauld Institute 37, 1974, pl. 36a).

\footnotetext{
${ }^{65}$ MODESTI, op. cit. (n. 47), p . 207.

${ }^{66}$ M. B. HALL, op. cit. (n. 46), p. 337; T. CREISSEN, op. cit. (n. 47), p. 180-1.

${ }_{7}^{6}$ W. EFFMANN, Die Kirche von Valeria zu Sitten und ihr Lettner, in Zeitschrift für Christliche Kunst 5 1903, S. 135-142.

${ }^{68}$ The pattern is usual for the $15^{\text {th }}$ c. MODESTI, op. cit. (n. 47), p. 47.
} 
southern gate appears as a redundancy, without sufficient functional connection with the bema, thus suggesting that it probably imitated a more elaborate model. If our concept proves right, the next question posed is the definition of the actual identity of this iconographic prototype.

The question is practically unanswerable, since the archeological evidence is scanty. The sole choir partition found at the Helladic area is traced at Glarentza of the NW. Peloponnesus. The remnants of a Lettnerwand (single wall partition) have been found by D. Athanassoulis in the middle of the single aisled Gothic church of the site, $\left(43,30 \mu . X_{14}, 90\right.$ m.) (ca. 126o). The edifice is identified with the famous church of St. Fransiscus of the Minorites, where the assemblies of the Franc rulers of Achaia took place ${ }^{69}$. As far as Crete is concerned, we know that the activities of the Latin religious Orders also included the foundation of convents mainly in urban centers ${ }^{70}$. The surviving archaeological evidence from these churches does not offer sufficient evidence for the existence of choir partitions. One could suggest with relative certainty that the impressive church of St. Peter at Chandakas, founded by the Dominicans in the $2^{\text {nd }}$ half of the $13^{\text {th }} \mathrm{c}$., was equipped with a tramezzo since the partition is obligatory for the churches of the Order already from the decrees of $1249^{71}$. The most important testimony for the existence of a tramezzo in a Cretan church derives from the 1620 exposition of the Catholic Bishop of Canea Giorgio Perpignano. The description refers to the cathedral of the city and cites ${ }^{72}$ :

Il choro di lunghezza di passa cinque, et di larghezza passa quattro, ove è la sedia episcopale di legno di lárese con 10 sedili di cipresso per gli canonici. Sopra l'altare grande v' è una pala dov'è dipinto il giudizio universale. Avanti detto choro in alto un Crucifisso grande con due figure, cioè $S$. Giovanni et della Madonna, sotto il quale pendono lambade tre di lotton, l' una grande et le due mezzano stando sempre accese nanti il Smo Sacramento.

The text certifies with certainty the existence of a choir (ca. 8, 5 X 6, 6 m.) and refers to the bishop's cathedra and the priests' chairs that were placed inside the area. A large Rood with the complementary images of the Virgin and
John were fixed at an elevated point in front of the choir, while at the lower part there were three hanging lamps. The description implies the existence of a tramezzo with a fixed Rood. It is noteworthy that the Bishop's lengthy and detailed description of the church makes only a vague reference to the partition, possibly because the arrangement remained in situ still in the early $17^{\text {th }} \mathrm{c}$., despite the official directions of the Trent Council. The Cathedral of Canea $\left(14^{\text {th }}\right.$ c.) was destroyed during W.W. II, yet its ground-plan was designed by Gerola in the early $20^{\text {th }} \mathrm{C} .{ }^{73}$. The dimensions of the bay at the eastern part of the central apsis coincide with those given for the choir in the text. Consequently one can conclude that the choir partition was installed in front of the piers that defined the chancel of the church. Additionally the reference of the text to three hanging lamps implies their adjustment to three openings, thus a triple arcade, similar to the arrangement of our own group. This testimony permits us to presume that similar partitions could have been also existent at other Latin cathedrals or abbeys of the island ${ }^{74}$.

Eventually the possibility of the existence of an urban architectural model of Latin origin for our group of screens is not distant. The form and the monumentality of the screens at Vutufou and Margarites display the great expectations of their founders. This ambitious process could include the selective imitation of an elaborate Latin model (tramezzo) and its subsequent adjustment to the Orthodox cultic needs. It is not a mere coincidence that in these churches survives a series of Latin decorative elements eventually "byzantinized". This concept offers us a better insight on the elements that constitute parts of the byzantinishe Ungehörigkeit of the Cretan churches, simultaneously posing questions for analogue Latin influences at other Helladic regions occupied by Francs or Venetians. Additionally it is unavoidable to pose another significant question regarding the commissioners' intentions. Could their will to imitate a Western liturgical furnishing mean apart from an aesthetic preference a religious osmosis? This is a question that cannot be answered at the present. For this answer we need to re study the whole mechanism of cultic transformations at the island of Crete during the late medieval era.

\footnotetext{
${ }^{69}$ The church has been constructed already in 1276, when it is discussed -inside the church- the petition for the Barony of Matergiffon. On the church and tramezzo: D. ATHANASOULIS, op. cit. (n. 9), p. 35-40; ID., Triangle of Power, Building Projects in the Metropolitan Area of the Crusader Principality of Morea, in S. GERSTEL (ed.), Viewing the Morea. Land and People in the Late Medieval Peloponnese, Harvard, 2013, p. 124-125. For the sources: A. BON, La Morée Franque, Recherches historiques, topographiques et archéologiques sur la Principauté d' Achaïe, Paris, 1969, P. 322, 576.

${ }^{70}$ For the subject: N.Tsougarakis, The Latin Religious Orders in Medieval Greece 1204-1500, Turnhout, 2012, 103-213.

${ }^{71}$ Possible remnants of arches of a tramezzo are localized at the southern wall of the nave, between the $3^{\text {rd }}$ and the $4^{\text {th }}$ chapel (Personal remark of Margit Mersch/D. Cooper). Yet the interpretation remains speculative due to the successive modifications of the church. For the church: D. CHRONAKI-D

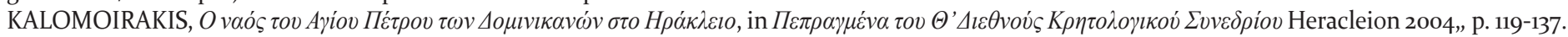
E. DELINIKOLA et al., Restoration of the Dominican Church of St. Peter in Heracleion, Crete, in Routes of Faith in the Medieval Mediterranean. History, Monuments, People, Pilgrimage Perspectives. Proceedings of an International Symposium, Thessaloniki 7-10/11/2007, Thessaloniki, 2008 , p. 430-440.

${ }_{72}$ U. MANNUCCI, Contributi documentarii per la storia dall distruzione degli episcopati latini in Oriente nei secoli XVI et XVII. 2. Aghien in Insula Creta, in Bessarione 18, 1914, p. 102.

73 G. GEROLA, op. cit. (n. 4), p. 64-5.

${ }^{74}$ For the influence of the Architecture of Mendicants on Crete: O. GRATZIOU, op. cit. (n. 1), p. 109-114.
} 